2014

\title{
The Virtues of Law in the Politics of Religious Freedom
}

Benjamin L. Berger

Osgoode Hall Law School of York University, bberger@osgoode.yorku.ca

Follow this and additional works at: http:// digitalcommons.osgoode.yorku.ca/olsrps

\section{Recommended Citation}

Berger, Benjamin L., "The Virtues of Law in the Politics of Religious Freedom" (2014). Osgoode Legal Studies Research Paper Series. 59. http://digitalcommons.osgoode.yorku.ca/olsrps/59 


\section{OSGOODE}

OSGOODE HALL LAW SCHOOL

YOR K U N I VERSITY

\section{OSGOODE HALL LAW SCHOOL}

LEGAL STUDIES RESEARCH PAPER SERIES

Research Paper No. 15/2014

Vol. 10, No. 5 (2014)

\section{The Virtues of Law in the Politics of Religious}

\section{Freedom}

Forthcoming in Journal of Law and Religion, Vol. 29, No. 3 (2014)

Benjamin L. Berger

\section{Editors:}

Peer Zumbansen (Osgoode Hall Law School, Toronto; Canada Research Chair in Transnational Economic Governance and Legal Theory - Editor in Chief)

Stephen Ji (Osgoode Hall Law School, Toronto - Production Editor) 
Osgoode Legal Studies Research Paper No. 15/2014

Vol. 10, No. 5(2014)

\title{
The Virtues of Law in the Politics of Religious Freedom
}

Forthcoming in Journal of Law and Religion, Vol. 29, No. 3 (2014)

\author{
Benjamin L. Berger
}

\begin{abstract}
:
The moral force and capacity for inspiration of both religion and politics alike arise in part from the sense that they authentically map the world as we find it, yielding claims about how it should be. This paper asks what role we might imagine for law in this "hyper-real" world of religion and politics, arguing that law can display distinctive virtues linked to its capacity for strategic agnosticism about the real. Applying Sunstein's idea of "incompletely theorized agreements" to the politics of religious freedom, the paper examines the role of law as a tool of adhesion in two very different constitutional settings - Canada and Israel and argues for modesty as a functional virtue in law and legal process. Viewed in this way, law draws its worth from its tolerance for ambiguity, its sub-theoretical nature, and its pragmatic proceduralism, seeking to sustain political community in the presence of normative diversity, rather than speaking truth to difference.
\end{abstract}

\section{Keywords:}

Religious Freedom, Politics, Incompletely Theorized Agreements, Modesty, Canada, Israel

\section{Author(s):}

Benjamin L. Berger

Associate Professor

Osgoode Hall Law School

York University, Toronto

E: bberger@osgoode.yorku.ca 


\title{
The Virtues of LAW in the Politics of Religious Freedom
}

\author{
Benjamin L. Berger*
}

Religion and politics alike are concerned with claims about the real. Their moral force and capacity for inspiration arise in part from the sincere conviction of religious and political believers that their respective creeds authentically map the world as we find it, giving rise to claims about how it should be.

Resisting a reductive tradition that approaches religion as false consciousness, wish, or "illusion," Clifford Geertz captured this feature of religion-its insistent realism-when he claimed that, amidst the vast diversity of religious systems, the unifying feature is that all assert "that the good for man is to live realistically; where they differ is in the vision of reality that they construct." 1 The source of religion's ethical force, Geertz explained, "is conceived to lie in the fidelity with which it expresses the fundamental nature of reality." 2 On this view, varieties of religious belief and practice do not have just symbolic differences - suggesting that understanding simply awaits a better or more sophisticated hermeneutic that can crack the semiotic code to find common human experience or existential concern-but differ, instead, on what realities impel their rituals and behaviours and make them sensible. This is an attractive, or at least useful, approach to religion inasmuch as it gives a persuasive account of the depth and force of religious culture. On this view, the bedrock of religion is ontological, not imaginary. Religion is hyper-realistic.

Politics makes a similarly strong set of claims about the real. The political is sensible and [a/e]ffective to the extent that it achieves a reflective fit with a set of beliefs about the world as we find it. To be sure, contending political visions differ on the incidence, source, and nature of injustice and inequality, all of which involve a certain type of claim about the real. Yet the realism that underwrites politics has even deeper and more fundamental

\footnotetext{
* Associate Professor, Osgoode Hall Law School, York University. Many thanks to Hannah Askew and Samara Secter for their research assistance and comments on earlier versions of this article and to Elizabeth Shakman Hurd and Winnifred Fallers Sullivan for their patience and generosity as editors.

${ }^{1}$ Clifford Geertz, The Interpretation of Cultures (New York: Basic Books, 1973), 130.

${ }^{2}$ Ibid., 126.
} 
features, drawing the force and coherence of the political from more basic ontological claims. All politics is premised on a claim about the true nature of the human being. Discriminations between what is a natural feature of human life and what is mutable or contingent are fundamental to the political, whether for Marx's view of social and human reality or the assumptions of naturalness and changeability through will that undergird modern liberalism. Is the "traditional family form" an ontological given or a social artifact? Divergent answers impel divergent politics. Whether radical or merely tonal, differences in politics float on claims about the real, claims that both impel and make reasonable certain policies, particular institutions, and specific forms of community.

The seriousness of these ontological disputes casts the politics of religious freedom in a provocative light; the question of the politics of religious freedom is, in one dimension, a question of the space afforded to, and the authority enjoyed, by the consequences of these realistic claims. If this casting of the issue captures some truth of the matter, it then raises a nest of interesting questions. The focus of this article is but one of those questions: what is the position of law within the politics of religious freedom? What role should law play on this ontological terrain? In the politics of religious freedom, does and should it fall to law and adjudication to make choices about the real, to settle these contesting claims?

Note the magnitude of the task if this is how we imagine the role of law faced with deep religious and normative difference. The demand is that the legal process should seek to capture reality-that its authority and legitimacy depends on a faithful tracking of the world as we find it. There is no doubt some intuitive appeal in that position. And, indeed, this is something that the rhetoric of law seems to endorse; the day-to-day life of law is very much concerned with "finding facts," a confident way of speaking about one's relationship to the real if there ever was one. However, set loose on the kinds of claims that animate religion and politics, imagining this kind of arbitral role for law between the realism of politics and religion sets it up for failure and disappointment. Moreover, this view of law's role makes it particularly vulnerable to a certain form of critique because, unsurprisingly given the nature of the institutions of law and the immediacy of its purposes, its interventions always turn out to be partial (in both senses of the word), forceful, and themselves cultural, expressing an animating frame of belief and ontology. ${ }^{3}$ On this view of law's role, legal process reaches the vanishing

\footnotetext{
${ }^{3}$ Much of my work has been concerned with showing this "cultural" nature of the constitutional rule of law, an understanding of law that sees it as one kind of relationship between worldview and ethics, to use Geertz's language. See Benjamin L. Berger, "Law's Religion: Rendering
} 
point with a secular politics that crafts policy based on a set of claims about human nature and the order of things.

We could imagine two sets of objections to this role for law. The first is a familiar kind of critical legal studies complaint. To imagine that law should settle claims about the real extends law's domain too far, making it an ontological player and putting judges in the unacceptably ambitious and under-legitimized role of purveyors of truth. Nothing should lead us to believe that the institutional practices of courts and the training of judges and lawyers give any particular access to insight into the most basic concerns animating debates about politics and religion. When law arrogates such authority to itself-or is asked to assume this position-it will fail in its ambition and, in the process, will favor a political position under a false conceit of its neutrality. I have great sympathy for this complaint.

Yet a second objection colors the issue somewhat differently, focussing less on the substantive shortcomings of law and more on the lost potential of legal process. The worry here is that the pretence of having law accurately capture reality distances it from virtues that might make it an attractive device of social ordering. It is this second concern that I want to explore in this piece: the idea that in a hyper-real world of religion and politics, law can display virtues linked to its capacity for strategic agnosticism about the real.

In a sense, this article is a reconstructive effort that looks beyond powerful critiques of law's role in the politics of religious freedom in an effort to imagine a productive role for law in a world hot with politics and religion. These important critiques participate in the first objection sketched above, focussing on the failures of law to match up to reality in satisfying ways and the distortions that this brings to the politics of religious freedom. Consider, for example, Winnifred Sullivan who has argued that religious freedom in law is, in fact, impossible. ${ }^{4}$ To legally protect religion demands a

Culture" Osgoode Hall Law Journal 45 (2007): 277-314; Benjamin L. Berger, "The Cultural Limits of Legal Tolerance, " Canadian Journal of Law and Jurisprudence 21 (2008): 245-278.

${ }^{4}$ Winnifred Fallers Sullivan, The Impossibility of Religious Freedom (Princeton, NJ: Princeton University Press, 2005). I draw on Sullivan as an example from a group of those who offer critiques of law and institutions of liberal secularism as they are applied to religious difference: see, e.g., Talal Asad, Formations of the Secular: Christianity, Islam, Modernity (Stanford, CA.: Stanford University Press, 2003); Saba Mahmood, Politics of Piety: The Islamic Revival and the Feminist Subject (Princeton, NJ: Princeton University Press, 2005), ; Wendy Brown, Regulating Aversion: Tolerance in the Age of Identity and Empire (Princeton, NJ: Princeton University Press, 2006). For an example drawn from the Canadian scholarship, see Lori G. Beaman, Defining Harm: Religious Freedom and the Limits of the Law (Vancouver: University of British Columbia Press, 2008). 
definition of religion, and any effort by law to define religion will necessarily misunderstand it. The conundrum so revealed is not merely interesting; it means that the power of the state will be deployed in favour of some religion and will burden or limit others. Understood in the frame of this article, Sullivan's is a critique of the legal attempts to map reality. It is an important claim, and nothing in this piece resists its conclusions. Indeed, to show the inquiring spirit of this article, I hasten to note my own participation in similar critiques. I have argued that law inevitably works on religion through cultural lenses that make religious freedom irredeemably partial. ${ }^{5}$ Law enacts and affirms peculiar conceptions of subjectivity, of authority, even of space and time. ${ }^{6}$ Awareness of this cultural nature of the rule of law-and of the power and violence that it deploys-should invite a healthy scepticism for a vision of law as an arbiter for the world of religious and cultural difference.

Critiques of law's role in the politics of religious freedom are both prevalent and important. Can anything be redeemed for law and adjudication in the context of deep religious difference?

This article reverses the flow of inquiry to offer a provisional defense of law based on, not in spite of, its failure to capture some kind of larger or common claim about the real. I will suggest modesty as a functional virtue for law, making legal process an attractive device that can at times be used to find relief from the saturated hyper-reality of religion and politics. The article walks around this issue by looking at a theoretical scheme that gets us some way into thinking about the virtues of law between politics and religion, virtues that trade on law's nature as always unfinished and under-inclusive of reality. This piece then draws from case examples in two very different politics, beginning on terrain with which I am most familiar, Canada, and then offering some provisional ways in which one might also see these at play in a setting in which the politics of religious freedom are differently contested, namely Israel. Ultimately my claim is that law can serve as a ground for adequate (if not entirely satisfying) theorization, one that finds the virtue of legal process not in its authoritative capacity to pronounce the

\footnotetext{
${ }^{5}$ See footnote 3 .

${ }^{6}$ For the conceptual foundations of such a claim, see Paul W. Kahn, The Cultural Study of Law: Reconstructing Legal Scholarship (Chicago: University of Chicago Press, 1999). On the "aesthetic" dimensions of religious freedom - those that implicate peculiar conceptions of space and time - see Benjamin L. Berger, "The Aesthetics of Religious Freedom," in Religious Freedom and Varieties of Establishment, eds. Winnifred Fallers Sullivan and Lori Beaman (Ashgate, forthcoming 2013).
} 
real, but its capacity to sustain civic engagement in spite of deep disagreement.

\section{Ambition and Modesty in Law}

There is a certain temptation to demand a high degree of integrity from a legal system. Law, it is hoped, can achieve a kind of thoroughgoing coherence, in which we could see through the results in particular cases to discern a governing theory that represents the immanent logic of the system. These approaches rest, of course, on the faith that there is such a logic to be found, as well as on the tacit assumption that this kind of governing theory is necessary for a well-functioning system of justice. This temptation to find coherence all the way from informing theory to specific adjudicative outcome is commonly indulged in academic treatments of law and finds expression in a wide range of approaches. There is, of course, the abundant literature seeking Kantian accounts for various aspects of the legal system, be it private law or approaches to punishment and sentencing. ${ }^{7}$ Economic theories of law, utilitarian accounts, and liberal claims are united in their desire to cast adjudication in the role of the one place in government in which theory might be purely expressed in practice. As Sunstein notes in the piece from which I will be drawing in this section, Dworkin's theory of adjudication is an ambitious claim for this version of "integrity" in judgment. Dworkin asks for "a high degree of theoretical self-consciousness in adjudication,"8 calling upon judges to turn to abstract theories of a community's legal practice in an effort to resolve the knotty cases before them. Hercules' adjudicative muscles are developed through heavy theoretical lifting. There is intuitive, not to mention emotional and aesthetic, appeal in such claims. The intuition is that just results in given cases demand a coherent view of the whole, and the hope is that the deliberative, argumentative, and relatively perspicuous medium of law is the one place in government where we might find an opportunity to do deduction well. The emotional and aesthetic appeal lies in the promise of conceptual order.

\footnotetext{
${ }^{7}$ See, e.g., Arthur Ripstein, Force and Freedom: Kant's Legal and Political Philosophy (Cambridge, MA: Harvard University Press, 2009); Ernest J. Weinrib, "Private Law and Public Right" (2011) 61:2 UTLJ 191; Malcolm Thorburn, "Constitutionalism and the Limits of the Criminal Law" in The Structures of Criminal Law, ed. R.A. Duff, Lindsay Farmer, S.E. Marshall, Massimo Renzo, and Victor Tadrow (Oxford: Oxford University Press, 2011), 85-105.

${ }^{8}$ Cass R. Sunstein, “Incompletely Theorized Agreements" Harvard Law Review 108 (1995):1733-1772.
} 
The politics of religious freedom seem to heighten this temptation, inviting a turn to law and adjudication as a forum in which deep disagreement at the level of basic principles can be resolved reasonably. The kinds of disputes generated by sharp divergences in religious and political views have a centrifugal force to them, pushing towards bigger and broader fundamental claims about the social good or, as I have explained, the "really real." And so debates about the legal status of same sex marriage or the criminalization of polygamy become debates about the nature of family, contests over abortion or euthanasia become conflicts about the idea of sanctity of life, and issues generated by the public display of religious symbols are framed as demanding answers about the nature of secularism and modern liberal democracy. The urge to meet such disputes on the terrain of high theory seems natural enough, and it is little wonder that issues of religious freedom and religious difference have occasioned so much worry about finding a theoretical ground on which agreement through law can be achieved in spite of the politics of religious freedom. Rawls' theory of public reason is precisely this: the search for a set of abstract political commitments that could cut through the fundamental conceptual differences that characterize deep religious and political difference. ${ }^{9}$ And of course adjudication would play a key role in the deployment of these commitments, constitutional courts serving as an exemplar of public reason, equipped with a political conception of justice and the veil of ignorance.

In his 1995 article "Incompletely Theorized Agreements," 10 Cass Sunstein challenges the wisdom of this approach, inviting a different way of thinking about the use of law in the midst of deep theoretical and conceptual difference. Religion and religious difference were not the focus of Sunstein's text, but the years since the article was published suggest that his framing of the role of law in navigating sharp social disagreement has particular relevance for thinking about adjudication in the field of religious freedom and could recover a salutary role for law amidst the heavily theorized domains of religious and political thought. Sunstein's call for attention to the virtues of incompleteness in adjudication stands as a strong counterpoint to the kinds of approaches-be they Kantian, utilitarian, or Rawlsian-that

\footnotetext{
${ }^{9}$ John Rawls, Political Liberalism (New York: Columbia University Press, 1996).

${ }^{10}$ Sunstein, "Incompletely Theorized Agreements." Sunstein further explores the ideas introduced in this article in subsequent work, including Legal Reasoning and Political Conflict (New York: Oxford University Press, 1996); One Case at a Time: Judicial Minimalism on the Supreme Court (Cambridge, MA: Harvard University Press, 1999); "Beyond Judicial Minimalism," Tulsa Law Review 43 (2008):825-842. I will be primarily working with his articulation of these ideas in "Incompletely Theorized Agreements."
} 
make more ambitious claims for law's capacity to theorize its way to just results. He notes that it is "customary to lament an outcome that has not been completely theorized, on the ground that any such outcome has been inadequately justified."11 Yet Sunstein finds value in the incompleteness of adjudication, rather than assessing law against the ambitious standard of thorough vertical coherence all the way from broad commitment to particular outcomes: "[T]here are special advantages to incompletely theorized agreements in law (and elsewhere)." 12 It is these benefits of incompleteness in adjudication, I will argue, that can and do play a special role in the legal management of the politics of religious freedom. ${ }^{13}$

The work of the judge, Sunstein explains, must be understood in the particular context of social pluralism in which she finds herself today. Judges "must operate in the face of a particular kind of social heterogeneity: sharp and often intractable disagreements on basic principle." 14 It may be that, in some instances, points of significant agreement can be found where they at first seemed elusive. But if one takes seriously the nature and depth of the differences that divide people along religious and political lines, it must also be acknowledged that shared commitment to abstract principles will often prove impossible, despite what liberal theorists assert. At such moments, Sunstein suggests that legal systems have a unique tool at their disposal that can be used to produce social cohesion in the context of significant pluralism on foundational matters: the capacity to focus agreement on more modest particulars and frames of analysis, rather than demanding consensus on abstractions. Sunstein explains that "when people diverge on some (relatively) high-level proposition, they might be able to agree if they lower the level of abstraction. People are sometimes able to converge on a point of less generality than the point at which agreement is difficult or impossible."15

\footnotetext{
11 "Incompletely Theorized Agreemnts," 1738.

${ }^{12}$ Ibid., 1738.

${ }^{13}$ The virtues of incomplete theorization are not limited to the adjudicative setting, of course. Other political institutions could well benefit from these practices of modesty and a focus on midlevel principles. My particular concern in this article, however, is the distinctive role of law, as spoken by the courts, in the politics of religious freedom.

${ }^{14}$ Ibid., 1734.

${ }^{15}$ Ibid., 1740-41. In a review of Sunstein's theory in the context of an argument about the legal protection of religious symbols in public institutions, ten Napel and Theissen describe incompletely theorized agreements as making "constructive use of silence on foundational or fundamental issues." Hans-Martien Th.D. ten Napel and Florian H.K. Theissen, "The Judicial Protection of Religious Symbols in Europe's Public Educational Institutions: Thank God for Canada and South Africa " Muslim World Journal of Human Rights 8 (2011): n.p.
} 
Similarly, people may be able to agree on a framework or set of mid-level principles without agreeing or-and this is key-having to agree on what those principles will demand in all imaginable future cases. In this sense, agreements achieved through law can be "incompletely theorized" in a number of different ways: Sunstein explains that such agreements could be "incomplete" insofar as they are (a) incompletely specified, leaving future cases unclear, (b) incompletely abstracted, showing agreement on mid-level principles, but not on the larger frame or conceptual foundation, or (c) incomplete in that they agree on an outcome and the low-level justifications for those outcomes, but do not require any agreement on large scale theories. The ability to bracket more comprehensive or specific claims in favour of a workable solution is the everyday stuff of law; indeed, Sunstein emphasizes that a key function of law is "to allow people to agree on the meaning, authority, and even the soundness of a governing legal provision in the face of disagreement about much else." 16

This is not just a pragmatic claim. The incomplete nature of many legal outcomes has a normative political dimension; these kinds of resolution are "an important source of social stability and an important way for diverse people to demonstrate mutual respect." 17 Incomplete agreements are not a privative form of reasoning or a necessary evil; rather, they are an important part of both public and private life. They "promote a major goal of a heterogeneous society: to make it possible to obtain agreement where agreement is necessary, and to make it unnecessary to obtain agreement where agreement is impossible."18 In this respect, Sunstein notes that "incompletely theorized judgments are well-suited to a moral universe that is divisive and pluralistic."19 Leaving open issues of basic principle when differences on these points seem unbridgeable, and leaving future cases somewhat unsettled when to do more would seem unwise, is a particularly sensible practice within the institutional constraints of legal decision making. Furthermore, leaving agreements incompletely theorized reduces the political stakes of winning and losing in court, saying only that you have not won the day in this given case, without more sweeping claims about the legitimacy of your basic norms or their potential relevance in future cases. ${ }^{20}$

\footnotetext{
16 "Incompletely Theorized Agreements," 1741.

${ }^{17}$ Ibid., 1736.

${ }^{18}$ Ibid., 1743 (emphasis in original).

${ }^{19}$ Ibid., 1748.

${ }^{20}$ As Sunstein puts it in reference to the losers of a given case, "[t]hey lose a decision but not the world.” Ibid., 1748.
} 
This posture of modesty allows for learning and evolution within the law over time and conserves social resources when insisting on more comprehensive agreement would be too costly. This strategic incompleteness is thus an expression of "the distinctive morality of judging in a pluralistic society." 21 It is "the lawyer's distinctive solution to the problem of social pluralism." 22

Rather than evaluating legal decisions based on how they fare as authoritative expressions of social or political morality, or as clear instructions for future conduct-both standards that seem philosophically and politically destined to fail-perhaps it is wiser to seek legal judgments that are good enough, abjuring more comprehensive conceptual judgments and more forceful prescription. This approach to law is attractive in its modesty, redeeming "adequacy" as an invaluable standard for judging legal outcomes, particularly in the context of deep political and religious difference. Of particular interest to me in this article is the way in which this view of adjudication opens up possibilities for seeing a constructive role for law in the politics of religious freedom, an account of legal process as a respite from the saturated hyper-reality of religion and politics.

In the following I will look at two cases, drawn from two very different social and political contexts, that can be read as showing some of the possibilities of a law that embraces the virtues of incompleteness when engaging in the politics of religious freedom. The overarching claim is that, in spite of the limits and partiality of law as an expression of liberal political culture, and the internal paradoxes and inconsistencies that it necessarily entails, we can nevertheless identify value and potential in the resort to legal process in the saturated world of religion and the political. One need not endorse or concur in the result in these cases to be able to find aspects of each that offer lessons for what law might be able to contribute to the vexing encounters of religion and the political. I will look more closely at a case drawn from the Canadian experience, turning then to a more tentative set of observations about an example drawn from a very different configuration of law, politics, and religion in Israel.

\footnotetext{
${ }^{21}$ Ibid., 1760.

${ }^{22}$ Ibid., 1769.
} 


\section{Canada: The Importance of Law's Incompleteness in Law and Religion}

The Canadian example crystallized in a Supreme Court of Canada decision in late $2012, R$. v. N.S.. ${ }^{23}$ The case concerned a sexual assault complainant who sought to wear the niqab while giving testimony at a preliminary inquiry. The niqab would cover her entire face, save her eyes. Would this be permitted in the context of the common law adversarial trial, which has traditionally relied so heavily on the assumption that observing the demeanour of the witness was a valuable aspect of the trial process and the assessment of credibility? The case produced a sharply divided Supreme Court, yielding three sets of reasons reflecting three very different approaches to the issue.

The question of whether a witness should be permitted to cover her face on religious grounds during a trial process was one expression of a broader set of questions regarding religious signs-and, more particularly, gendered symbols in Islam-both within Canada and internationally. Within Canada, in 2011, the then Federal Minister of Citizenship and Immigration, Jason Kenney, announced that women would not be permitted to wear the niqab while taking the oath at citizenship ceremonies. According to Minister Kenney, "[a]llowing a group to hide their faces while they are becoming members of our community is counter to Canada's commitment to openness, equality and social cohesion." 24 Although it seemed that no formal steps were routinely taken at immigration ceremonies to ensure that all new citizens were actually saying the oath, the display of one's face nevertheless took on particular symbolic import aligned with inclusion in the national community. Indeed, Minister Kenney would later explain that, apart from any difficulty in verifying that individuals were actually saying the oath, his concern was the public and legal nature of the activity: "It's a public licensing, a declaration of your membership in the community and you do that in front of your fellow citizens in public. To obscure yourself at that essentially public moment when you're making a legal undertaking in front of your fellow citizens undermines the nature of the public oath." ${ }^{25}$ A short time before, in early

\footnotetext{
232012 SCC 72.

24 “Niqabs, Burkas Must Be Removed During Citizenship Ceremoies: Jason Kenney" The National Post (December 12, 2011), http://news.nationalpost.com/2011/12/12/niqabs-burkasmust-be-removed-during-citizenship-ceremonies-jason-kenney/ (accessed May 13, 2013).

25 "Kenney on Transformational Changes to Immigration Model " The Globe and Mail (April 10, 2012), http:/www.theglobeandmail.com/commentary/editorials/kenney-on-transformationalchanges-to-immigration-model/article4099553/?page=all (accessed May 13, 2013).
} 
2010, the Liberal Government of Quebec had tabled Bill 94, which would prohibit anyone employed by the government to deliver a service and anyone accessing government services from doing so while wearing a face covering. This legislation was introduced following a pitched debate that arose after a niqab-wearing woman was expelled from French language classes because she refused to remove her face covering. As it was in France, this legal move was tethered to a conception of secularism, Premier Charest explaining that the Bill was a reflection of Quebec's commitment to "open secularism."

Of course these engagements between religion and politics on the issue of what Muslim women could or should wear in public were just a Canadian iteration of a yet broader debate. In France, most famously, the "Islamic Veil Affair" and the 2003 Stasi commission had produced legislation banning the display of "conspicuous religious symbols" in public schools, ${ }^{26}$ as well as broader conversations about the public display of religious identity. For Talal Asad, this debate in France was a debate about political authority expressed through assertions about the definition of the secular in the French religious and political tradition. It saw the state engaged in symbolic work, defining the meaning of a sign and then consolidating its authority in reaction to these meanings. Asad notes that it was not, ultimately, the veil itself that provoked state concern; rather, it was the act of displaying the veil, the will to display the symbol, that troubled a society in which secularism was thought to inhere in the universal character of republican legal identity. ${ }^{27}$ Fernando adds that debates about the veil were suffused with the problem of how to understand choice in the context of religious duty. ${ }^{28}$ Issues of gender, equality, authority, and freedom are all compendiously packaged in the politics surrounding the veil.

If one reads N.S. as one expression of this larger story, the breadth and difficulty of issues of political commitment, identity, and religious freedom raised by the case are notable. The problem that came before the Court was very clearly a part of larger (and lively) conversations about the real meaning

\footnotetext{
${ }^{26}$ See Talal Asad, "French Secularism and the 'Islamic Veil Affair" The Hedgehog Review (2006): 93-106; Mayanthi L. Fernando, "Reconfiguring Freedom: Muslim Piety and the Limits of Secular Law and Public Discourse in France" American Ethnologist 37 (2010): 19-35.

${ }^{27}$ John Bowen importantly shows that despite the political and rhetorical force of this public ideal of all citizens interacting with a French republican identity, unmediated by other associational allegiances, a rich associational life in fact subsists beneath this politics of common public identity: John R. Bowen, Can Islam Be French? Pluralism and Pragmatism in a Secular State (Princeton, NJ: Princeton University Press, 2010).

${ }^{28}$ Fernando, "Reconfiguring Freedom."
} 
of secularism in Canada, whether it meant something different in Quebec's distinctive political and social history, ${ }^{29}$ how it interacted with a commitment to multiculturalism, and how it related to the understanding of this concept in other parts of the world. The case also evoked definitions of political community, intersecting with politically charged claims about what it meant to be Canadian. Contending understandings of gender equality, of approaches to choice and duty, and of self-definition were all triggered by this sexual assault case, as were contests about orthodoxy and innovation, diversity, and authority within Islam. This was the complex of political and religious issues clustered around the N.S. decision.

Three sets of reasons issued from the Supreme Court of Canada, showing a significant divide within the Court on how to resolve the issue of witnesses wearing the niqab. Before turning to the differences among the reasons, it is worth noting that the three judgments agreed on much. All agreed that this case involved the meeting of two fundamental rights, freedom of religion and the right to a fair trial, and that the outcome in the case would turn on how the relationship between these two rights would be framed. ${ }^{30}$ All also agreed that the failure to see the full face of the witness derogated, to some extent, from the full package of information ideally available to the trial process, though they differed on the seriousness of the impact of deficit on the accused's fair trial right; in the words of Justice Abella, "seeing more of a witness' facial expressions is better than seeing less." 31

The majority decision, written by Chief Justice McLachin, selfconsciously navigated a course between the two more categorical solutions offered by the other judges who wrote, Justices LeBel and Abella. "One response," Chief Justice McLachlin wrote, "is to say she must always remove her niqab on the ground that the courtroom is a neutral space where religion has no place. Another response is to say the justice system should respect the witness's freedom of religion and always permit her to testify with the niqab on."32 Eschewing these "extremes," 33 the majority held that the proper

\footnotetext{
${ }^{29}$ For a discussion of the unique dimensions of Quebec's experience with secularism, see Jocelyn Maclure and Charles Taylor, Secularism and Freedom of Conscience (Cambridge, MA: Harvard University Press, 2011) and Geneviève Zubrzycki, "Identity, Religion, and Secularism in the Debate over 'Reasonable Accommodation,"' in Religion on the Edge: De-centering and Recentering the Sociology of Religion, (New York, NY: Oxford, 2013) pp. 215-237.

${ }^{30}$ This dualist framing of the issue in N.S. is itself open to criticism. One wonders how a robust inclusion of gender equality interests into the casting of the issue would have inflected the analysis.

${ }^{31} 2012$ SCC 72. Para. 82.

${ }^{32}$ Ibid., Para. 1.

${ }^{33}$ Ibid., Para. 1.
} 
approach would be a case-by-case balancing of the impact on the witness's sincerely held religious beliefs and the accused's interest in effective and fair cross-examination:

The answer is not to ban religion from the courtroom, transforming the courtroom into a "neutral" space where witnesses must park their religious convictions at the door. Nor does it lie in ignoring the ancient and persistent connection the law has postulated between seeing a witness's face and trial fairness, and holding that a witness may always wear her niqab while testifying. Rather, the answer lies in a just and proportionate balance between freedom of religion on the one hand, and trial fairness on the other, based on the particular case before the Court. ${ }^{34}$

The majority decision canvasses the importance of religious toleration and accommodation, and applies the "subjective sincerity test" developed in the Supreme Court of Canada's jurisprudence, whereby the test of whether one's religious freedom is affected turns not on the judgment of external authorities in the religion but, rather, on a court's conclusion that the religious belief or practice was sincerely exercised by the claimant and that the practice was more than trivially interfered with. ${ }^{35}$ Chief Justice McLachlin similarly emphasized the importance of effective credibility assessment and cross-examination to the prevention of unjust results and wrongful convictions. While conceding that the value of observation of the witness' face was subject to some debate, the majority remarked on the weight of tradition and the strong assumption within the common law trial that observation matters, noting the absence in the record of strong expert evidence displacing this assumption. In the end, the majority settles on a case-by-case approach that it summarized as follows: "where a niqab is worn because of a sincerely held religious belief, a judge should order it removed if the witness wearing the niqab poses a serious risk to trial fairness, there is no way to accommodate both rights, and the salutary effects of requiring the

\footnotetext{
${ }^{34}$ Ibid., Para. 31.

${ }^{35}$ This test was created in Syndicat Northcrest v. Amselem, [2004] 2 S.C.R. 551, 2004 SCC 47, and has since been discussed and explained in a number of cases, including Alberta v. Hutterian Brethren of Wilson Colony, 2009 SCC 37, [2009] 2 S.C.R. 567 and S.L. v. Commission scolaire des Chênes, 2012 SCC 7, [2012] 1 S.C.R. 235. For a critical assessment of this test, see Berger, "Law's Religion" and "The Cultural Limits of Legal Tolerance."
} 
witness to remove the niqab outweigh the deleterious effects of doing so."36 Chief Justice McLachlin provides some guidance as to how to weigh these factors, noting, for example, that the broader societal harm of discouraging the reporting of sexual assault offences should be borne in mind; however, the majority refrained from pronouncing a strict rule one way or the other, leaving this general framework to the application of trial judges.

Justice LeBel issued separate reasons, concurring in the result, but would have articulated a firm rule prohibiting witnesses from wearing the niqab in Canadian courtrooms. Although he recognized the importance of religious rights, he emphasized that "there is more to this case"-that the case was also about "the growing presence in Canada of new cultures, religion, traditions and social practices" 37 and how courtrooms as key public spaces should be understood in that context. Justice LeBel conceded that his approach led to "further questions about the meaning of multiculturalism in our democratic environment". ${ }^{38}$ His answer to those questions was that, as important as multiculturalism is to Canadian life, certain common values and institutions were nevertheless required. For Justice LeBel, "[t]he religious neutrality of the state and of its institutions, including the courts and the justice system, protects the life and growth of a public space open to all regardless of their beliefs, disbeliefs and unbeliefs. Religions are voices among others in the public space, which includes the courts." 39

Justice Abella dissented, reasoning that, excepting very rare circumstances in which the identity of the witness was at issue, a witness should be permitted to wear the niqab while testifying. Justice Abella described the "crux" of the case very differently than Justice LeBel: to Justice Abella, the result turned on her assessment that "the harm to a complainant of requiring her to remove her niqab while testifying will generally outweigh any harms to trial fairness." 40 Chief among the harms of requiring removal of the niqab would be the chilling effect on complainants alleging sexual assuault: in the context of sustained social efforts to make the judicial system more responsive to sexual crime, "[c]reating a judicial environment where victims are further inhibited by being asked to choose between their religious rights and their right to seek justice, undermines the public

\footnotetext{
${ }^{36} 2012$ SCC 72, Para. 46.

${ }^{37}$ Para. 59.

${ }^{38}$ Para. 61.

${ }^{39}$ Para. 73.

${ }^{40}$ Para. 86.
} 
perception of fairness not only of the trial, but of the justice system itself." 41 In the end, she was prepared to conclude that wearing the niqab did not present a serious risk to trial fairness ${ }^{42}$ and that "the harmful effects of requiring a witness to remove her niqab, with the result that she will likely not testify, bring charges in the first place, or, if she is the accused, be unable to testify in her own defence, is a significantly more harmful consequence than not being able to see a witness' whole face." 43

The majority decision in N.S. has been met with a number of criticisms. The most compelling, in my view, is that the harms of discouraging sexual assault complaints far outweigh a partial loss of one element of the "whole demeanour package," 44 particularly when the system accommodates such departures in other situations. The most common critique heard after the decision, however, was that the majority decision simply decided too little. Justice LeBel called for a "clear rule" rather than the case-by-case approach and subsequent media commentary echoed his call. Some characterized the majority approach as quintessentially Canadian, and this was not intended as flattery. It is this more common critique that interests me in this article. Whatever else one might think of the decision, did it "decide too little?" A good hard look at this question in the broader context of debates about the niqab yields an interesting response: the majority's decision was seriously incomplete in its theorization... and this might just be a good thing.

Recall what was impacted around this case: claims about Islamic orthopraxix and the status of the niqab as choice or duty, religion or culture; complicated questions about the nature of women's autonomy within religion and visions of gender equality; and most intensely, an extremely complicated and lively political debate about the nature of Canadian secularism and the demands of multiculturalism. To this list of issues one can add serious questions about the truth behind cross-examination and credibility assessment and the weight and wisdom of common law trial tradition. On the issue of demeanour evidence, the majority seized on the weakness of the record and deferred stronger claims about the value of observation to future cases and better science. More to the heart of the political and religious issues with which this case was freighted, resorting to a case-by-case approach and a balancing framework allowed the majority to

\footnotetext{
${ }^{41}$ Para. 95.

${ }^{42}$ Paras. 90, $97 \mathrm{ff}$.

${ }^{43}$ Para. 109.

${ }^{44}$ Per Abella J., para. 91.
} 
stay its judgment on more conceptual points subject to deep and persistent contestation, and on which agreement was neither forthcoming nor necessary. Justice LeBel's more categorical approach required him to ascend to claims about the demands of multiculturalism, the nature of secular public spaces, and the "values of the Canadian justice system". ${ }^{45}$ Canadian society has carried on quite well while precisely these issues are debated in political and religious circles; the N.S. decision could be a moment for the attempted resolution of those debates, suggesting a legal "answer" to this political exchange, or it could sustain them. The majority's less theorized approach allowed it to withhold judgment on the relative priority of various rights, while also leaving aside broader pronouncements on foundational visions of equality and claims about autonomy and choice within religion. At the same time, this approach refused to offer a rule for future cases, thereby "incompletely theorizing" the future and possible negotiations and accommodations that might be found through time and experience.

Finally, there is a way in which the Canadian jurisprudence on freedom of religion more generally shows the features and benefits of incomplete theorization. The Court's "subjective sincerity test," whereby the genuineness of a given religious belief or practice is assessed by reference only to the sincere subjective views of the claimant (rather than by appeal to orthopraxis, text or external religious authority) moves issues from the soaring heights of theology and history to the more modest, and more familiar, terrain of credibility assessments. This leaves aside the question of the authenticity of a given religious precept or practice-in this case the wearing of the niqab in the complex and heterogeneous religious infrastructure of Islam-and curbs the impulse towards the Sisyphean project of finding agreement on such points.

Indeed, one might understand balancing and proportionality testswhich have risen to global prominence as the organizing logic of constitutional adjudication-precisely as tools of conceptual descent and predictive modesty. Such approaches permit the affirmation of multiple points of mid-level principle-for example, on the importance of religious freedom, multiculturalism, and fair trials-without requiring grander juridical or social theories, thereby avoiding the more fierce and absolute claims that circulate in the politics of religious freedom. The use of these tools also allows for and even foments an attractive species of untidiness engendered by a diversity of localized outcomes, which is where the creative genius of democratic politics can take place.

${ }^{45}$ Para. 61. 
Incomplete theorization is not a universal good-as Sunstein himself emphasizes ${ }^{46}$-nor is balancing a test for all seasons. Sometimes firmer decisions can and must be made, whatever the impact on social stability and mutual respect among political adversaries. Perhaps N.S. was one such case. But with a strategic agnosticism about grand theories, future outcomes, or both, law can serve a role in holding us in disagreement while allowing us to get along with the messy business of living together in pluralist societies.

\section{Israel: Legal Process and Balancing as Conceptual Descent}

With respect to the challenges surrounding religious diversity and political difference, Canada and Israel seem to share little. Important and trying though the Canadian experience of religious multiculturalism is, it feels a world apart from the pitched and open religious conflict that afflicts the Israeli social and political landscape. The intensity of these matters in Israel is, of course, traceable to a number of features of the history and demographics of the country, involving the Jewish identity of the State asserted in the Declaration of Independence, the religious dimensions of the Israeli-Palestinian conflict, and the rich religious geography of the country, making the territory the home and focal point for a number of religions. The political system in Israel further exposes and underscores dimensions of the weaving together of religion and politics, with the electoral process yielding significant power for ultra-orthodox Jewish groups who wield substantial power in a legislature (Knesset) that depends on coalitions to govern. To turn to the Israeli case in thinking about the virtues of law and legal process in the politics of religious freedom is to switch into a very different register, indeed.

The specific expression of the politics of religious freedom in Israel that I want to focus on here is drawn from the conflict between the substantial ultra-orthodox, or "Haredi," minority population in Israel and the less orthodox and secular mainstream within the country. ${ }^{47}$ The Haredi live

\footnotetext{
${ }^{46}$ Sunstein, "Incompletely Theorized Agreements," 1746, 1767. As ten Napel and Theissen put it, "[a]t times, fundamental questions need be asked and answered in order for legal concepts like human rights to do what they were adopted for: to protect people against assaults on their life, liberty and dignity." ("The Judicial Protection of Religious Symbols," 5.) There may, indeed, be cases in which this more conclusory posture is appropriate in judicial decision-making. The argument in this piece is that the scope of this class is far narrower than normally imagined and that claims that "fundamental questions need be asked an answered" should be approached with some skepticism.

${ }^{47}$ The U.S. Department of State provides the following summary of the religious demography of Israel, as of 2011: "According to the 2009 report of the Central Bureau of Statistics (CBS), 8
} 
by distinctive interpretations of Jewish law and pursue a lifestyle that insulates them from less religious components of the population. ${ }^{48}$ Powerful political representation and a rapidly growing population have made Haredi interests a fact of the modern Israeli realpolitik and a flashpoint for public policy disputes. ${ }^{49}$ Tensions with the Haredi population in Israel-which have been volatile and, at times, violent-have appeared in matters concerning education, ${ }^{50}$ the use of public streets during religious holidays, ${ }^{51}$ and the exemption of the ultra-orthodox from military service. ${ }^{52}$ The Israeli Supreme Court has played an important role in these conflicts, ${ }^{53}$ with issues of gender equality and questions of religious toleration featuring centrally in many. ${ }^{54}$ So it is with the example that I want to examine in this article: the

percent of the Jewish population is Haredi (also known as "ultra-Orthodox"); 12 percent identify themselves as Orthodox; 13 percent describe themselves as "traditional, religious;" 25 percent say they are "traditional, not so religious;" and 42 percent describe themselves as

"nonreligious/secular" Jews, most of whom observed some Jewish traditions." U.S. Department of State, International Religious Freedom Report for 2011: Israel and the Occupied Territories, http://www.state.gov/j/drl/rls/irf/religiousfreedom/index.htm?dlid=192887, (accessed April 13, 2013).

${ }^{48}$ For a helpful description of the historical origins and modern nature of the Haredim, as well as a fascinating account of Israel's "multicultural condition" more generally, see Menachem Mautner, Law and the Culture of Israel (Oxford: Oxford University Press, 2011), $121 \mathrm{ff.}$

${ }^{49}$ For works assessing this schism within Israeli society, see Mautner, ibid.; Eliezer Ben-Rafael, "The Faces of Religiosity in Israel: Cleavages or Continuum?" Israeli Studies 13 (2008): 89-113; Uzi Rebhun and Chaim Isaac Waxman, Jews in Israel: Contemporary Social and Cultural Patterns (Hanover, NH: Brandeis University Press, 2004); Asher Cohen and Bernard Susser, Israel and the Politics of Jewish Identity: The Secular-Religious Impasse (Baltimore, MD: Johns Hopkins University Press, 2000).

${ }^{50}$ HCJ 1067/08, Noar Kehalacha Association v. Ministry of Eduction (2009) IsrLR 84.

${ }^{51}$ HCJ 6986/10, Azari v. Israel Police (2010), concerning segregation on the streets of Mea She'arim during Sukkot.

${ }^{52}$ See, most recently, HCJ 6298/07, Resler v. Knesset (2012).

${ }^{53}$ Although not the focus of this article, the story of the shifting role of the judicial branch in Israeli politics and culture is a lively and fascinating one from the perspective of both comparative constitutional law and political science. This still-unfolding story is expertly narrated and analyzed by Menachem Mautner in Law and the Culture of Israel. Significantly, Mautner traces the increased political and social prominence of Israel's Supreme Court and its jurisprudence in the 1980s and 1990s - what he describes as part of a "spellbinding process of cultural change" (144) - to cultural anxiety among the liberal establishment in the country, provoked in part by the political rise of the ultra-Orthodox population.

${ }^{54}$ For articles canvassing cases arising in the context of this fissure between the Haredi and other parts of Israeli society, see Margit Cohn, "Taking a Bus from Immanuel to Mea Shearim: The Role of Israel's High Court of Justice in Regulating Ethnic and Gender Discrimination in the 
case of Ragen $v$. Ministry of Transport ${ }^{55}$ and the question of gender segregation on public bus transportation.

This case arose out of the desire of Haredi populations, which rely heavily on public transport, to have gender-segregated buses in which men and women would sit separately, with men at the front and women sitting at the rear of the bus. In about 2005, Egged, the principal provider of public bus services in Israel, began to offer gender-segregated bus lines servicing communities with large Haredi populations. Women would board from the rear door and sit at the back, with men boarding at the front. These bus lines -called "mehadrin" lines, literally meaning "meticulous", referring to the supposed care with which they apply Jewish law, or halakhah-began to attract substantial controversy as non-Haredi women who refused to abide by this customary arrangement were harassed, harangued, and sometimes threatened into compliance with the religious norm, at times assisted by the operators of the buses. In 2007 a petition was filed before the Supreme Court in which the petitioners sought a ruling prohibiting these lines. As Justice Rubenstein would put it in his lead reasons when the decision was ultimately released in 2011, what the Court had before it was "yet another issue that presents and represents a typical dispute between fractions of Israeli society." 56

At the heart of the case is, of course, a fierce collision between norms of gender equality and religious ways of life. The Court itself notes the resonances-as well as the differences-with issues of bus segregation in the American South, and the way in which the case evokes fundamental issues regarding discrimination and equality in public spaces. Yet the case also evokes larger debates about the place of the Haredi in Israeli society, questions that have been most volatile surrounding the exemption of the Ultra-Orthodox from otherwise mandatory and universal military service and the insulation of Haredi communities from the economic life of the

Haredi Ultra Orthodox Sector" (November 15, 2012), available at SSRN:

http://ssrn.com/abstract=2176401 or http://dx.doi.org/10.2139/ssrn.2176401 (accessed May 13, 2013); Ofrit Liviatan, "Judicial Activism and Religion-Based Tensions in India and Israel "Arizona Journal of International and Comparative Law 26 (2009): 583-621.

${ }^{55}$ HCJ 746/07, Ragen v. Ministry of Transport (2011).

${ }^{56}$ Ibid., para. 1 of Rubenstein J.'s decision. I am conscious that my inability to read Hebrew distances me from both the subtlety and nuance of the original language of the decision, as well as from the Hebrew scholarship on this and other related cases. The discussion that follows is based on the English translation of the decision available on the Court's website: http://elyon1.court.gov.il/files eng/07/460/007/t38/07007460.t38.pdf (accessed May 13, 2013). 
country. ${ }^{57}$ The mehadrin bus lines can also be read as a synecdoche for the fraught nature of secularism in Israel, serving as a microcosm for the tensions produced as the country seeks to navigate a course between liberal democracy and a religiously defined polity. The case evokes fraught conceptual and scholarly debates regarding the limits of multiculturalism and religious toleration. Religion, politics, discrimination, gender, and national self-definition are all live and at hand in this socially and theoretically pregnant case.

The Court's 2011 decision was unanimous but comprised of three sets of reasons, the lead reasons written by Justice Rubenstein, with Justices Joubran and Danziger writing short concurring decisions emphasizing certain points in Rubenstein J.'s judgment. To a reader unfamiliar with the work of the Court, the first notable feature of the case is the substantial process, and the Court's central role in managing that process, that occurred between the filing of the petition in 2007 and the release of this decision in 2011. As the case first presented, the parties were characteristically far apart. Yet in the first hearing in 2008 the Court urged the creation of a "new forum to examine the factual situations and the lessons of the years that have gone by and to issue recommendations". ${ }^{58}$ The Minister of Transport convened a committee that engaged in broad public consultation, including with the Haredi community, in 2008-2009. The Committee reported in 2009, concluding that the existing practice of enforced separation on these bus lines was illegal, as would be any signs officially suggesting such a separation. The Committee also concluded, however, that the religious demand for these separated lines was a real and substantial one and that informal separation should be allowed as long as no harm would be visited on those who chose not to comply. With those recommendations in hand, the parties again met with the Court in 2009. The Minister partially rejected the committee's recommendations, saying that although the existing coercive practices of segregation would be prohibited, "behaviour-directing" signs would be posted, with an option for individuals to ignore them. In February 2010 the Court held that the Minister would have to show cause why the recommendations of the committee should not be endorsed in full. The hearings continued later in 2010 and, in the intervening months, the Minister had changed positions. The minister was now prepared to adopt the recommendations in full, endorsing the Committee's recommendation prohibiting any formal coerced or optional separation but allowing for a trial

\footnotetext{
${ }^{57}$ See footnotes 49 to 54 .

${ }^{58}$ HCJ 746/07, Ragen v. Ministry of Transport (2011), para. 4 of Rubenstein J.'s decision.
} 
period in which riders would be permitted to board from both the front and rear doors. The hope was that this trial arrangement would allow a noncoerced informal ordering of the bus for those who wished to be separated on gender lines. In the end, when the matter finally came to decision before the Court, the dispute had been substantially narrowed owing to the fouryear process of fact-finding and negotiation inaugurated and overseen by the Supreme Court. The only remaining dispute between the petitioners and the respondents was whether the practice of opening the rear doors could continue, facilitating informal segregation on the bus.

And so before one even turns to the substance of the Court's reasoning-prior to any conceptual or theoretical claims being made on the part of law-one sees the legal process intervening to force parties into a form of inquiry and discussion that sustained political engagement through an otherwise volatile conflict. Against the backdrop of violent religious encounters and pitched politics surrounding these bussing practices, resort to legal process had, in this case, a procedural effect quite apart from any substantive judgments made by the Court.

With the dispute substantially narrowed, Justice Rubenstein was able to affirm what all parties had already agreed to-that the mehadrin lines as they were running were illegal and prohibited to the extent that they enforced or suggested gender separation in the provision of a public service-and to therefore characterize the issue in practical, and insistently non-theoretical terms:

The question with which the Committee is contending is in what way-and up to what point-is it possible to accommodate those persons and population groups who seek to use gender-separated public transportation, without placing the rest of the women (and men) who used public transportation, in prejudicial situations. We therefore take the bull by the horns. In contrast to the interesting theoretical questions of multiculturalism, attitudes toward women and attitudes toward the ultra-Orthodox population, the question before us is a practical one-namely, whether it is possible to arrive at voluntary alternatives within an open framework, whereby the alternatives in question would not merely be a disguise for forcible and insulting separation. ${ }^{59}$

\footnotetext{
${ }^{59}$ Para 7 of Rubenstein J.’s decision (emphasis added).
} 
Justice Joubran concurred in this assessment of the issue, emphasizing the practical and narrow nature of the problem before the Court. The framing of the issue in these terms meant that the Court could settle the conflict without resort to more comprehensive theories of religious multiculturalism, the relationships between gender equality and choice, and the limits of tolerance. Justice Rubenstein notes, for example, that there is an active scholarly debate on the issue of whether the state has an obligation to intervene in discriminatory practices within religious groups, emphasizing that this is a question on which positions very much differ. ${ }^{60}$ By contrast, the Court only needed to decide whether the rear doors of buses should be left open. And even this decision is approached with some diffidence: the Court notes that the trial period recommended by the Committee suffered from datacollection flaws and, accordingly, orders an extension of the trial period for a further year to determine whether this informal arrangement does, in fact, avoid coercion on the ground.

In this, the Court's focus on the practical nature of the narrowed dispute allowed it to withdraw from larger possible comprehensive claims. So doing simultaneously facilitated modesty on the range of outcomes that the Court had to specify in a highly complex and rapidly changing political and social setting. The Court needed only to offer a provisional measure to settle a narrow question: "we believe we should refrain, at this time, from a sweeping 'final' decision." 61 Released from both grand theory and searching detail, the Court's reasons focus on "mid-level" principles that can confirm points of common agreement and state general working values. And so the heart of the decision is the universal wrong of coercion. Justice Rubenstein characterizes the core feature of this case as "the element of coercion vis-àvis men and women passengers who are not interested in separation (within and outside ultra-Orthodox society)". ${ }^{62}$ Strongly affirming "the Israeli legal system's generally accepted concept of equality,"63 and despairing at the spectre of public segregation, Justice Rubenstein also notes that, if coercion can be avoided, not only should the religious community be permitted to act as they see fit, "it is even quite possible that we must try to help it to do so. This is because consideration of the religious needs and beliefs of every human being is one of the basic principles of the Israeli legal system." 64 In his

\footnotetext{
${ }^{60}$ Para. 31 of Rubenstein J.'s decision.

${ }^{61}$ para. 42 of Rubenstein J.'s decision.

${ }^{62}$ para. 29 of Rubenstein J.'s decision.

${ }^{63}$ para. 8 of Rubenstein J.'s decision.

${ }^{64}$ para. 8 of Rubenstein J.'s decision.
} 
separate reasons, Justice Danziger emphasizes non-coercion as the point on which all can surely agree, despite differences, asking rhetorically all men involved in the dispute "how they would feel if, merely because they belonged to a certain group, people were to fence off the public area in which they are entitled to be present and to require them to wear a certain type of attire."65 Respect for autonomy is the fulcrum for the Israeli legal system's strong commitment to both freedom of and freedom from religion.

Proportionality tests and balancing approaches have featured prominently in Israeli Supreme Court jurisprudence, a style of judicial reasoning championed by former President Aharon Barak. ${ }^{66}$ This brings us back to an observation that I made in the discussion of the Canadian case, that balancing might best be thought of as a device of theoretical descent. The logic of the decision in Ragen is one of balancing, with Justice Rubenstein endorsing the Committee's characterization of the essence of this case being the struggle of finding a non-coercive equilibrium between "the public's right to religious freedom and the protection of its religious sensitivities... and the right of women who are not interested in separation arrangements to freedom from religion-and, even more importantly, in my opinion, to dignity and equality." 67 Most interesting in the context of the themes of this article, and relying heavily upon Aharon Barak's extra-judicial writings, Joubran J. explains that "the requirement for proportionality" is "the proper legal framework for clarifying and fine-tuning the complex issues that arise in a multifaceted and multicultural state, which, unfortunately, is also characterized by rifts, such as Israeli society." 68 Such a framework is wellfitted to such societies because

[p]roportionality is a legal structure of balance, which is sustained by data external to it, and which can contain various theories of human rights.... Within the bounds of proportionality, the various theories of liberalism and multiculturalism can find their proper place. ${ }^{69}$

\footnotetext{
${ }^{65}$ para. 3 of Danziger J.'s decision.

${ }^{66}$ See, e.g., Aharon Barak, The Judge in a Democracy (Princeton, NJ: Princeton University Press, 2006) and Proportionality: Constitutional Rights and Their Limitations (Cambridge: Cambridge University Press, 2012).

${ }^{67}$ Para. 26 of Justice Rubenstein's decision.

${ }^{68}$ Para. 7 of Justice Joubran's decision.

${ }^{69}$ Para. 7 of Justice Joubran's decision.
} 
This account is intriguing. It suggests that the value of law lies not in the fidelity with which it effects a moral theory or theory of human rights (pace Dworkin, Kantians, etc.) - on its authority to speak truth-but, rather, in its capacity to be agnostic on precisely such points.

Given the constellation of significant legal and political questions raised by the case, with Ragen we are, again, presented with a decision that some might object decided too little. Yet there are ways of seeing long, involved processes and modest claims as the roots of the virtue of law amidst the politics of religious difference. Recall Sunstein's claim that "incompletely theorized judgments are well-suited to a moral universe that is divisive and pluralistic."70 Israel is, to be sure, one such moral universe. In a political context in which religious difference threatens the fracturing of society, what can law offer? One tempting answer adopts an oracular theory of adjudication, looking to judges to articulate the immanent moral truth of the political order. There are, to be sure, moments when this is precisely what a polity needs. ${ }^{71}$ And yet another answer, fitted for other cases and the one suggested by my reading of Ragen, would have the law meet deep normative difference with process, mid-level principles, and strategic agnosticism, offering a kind of shelter from the politics of religious difference and deferring a more complete truth for other times, and other fora.

\section{Conclusion: Law as a Tool of Adhesion}

Critical literature in the field of law and religion has identified certain gaps, paradoxes, and even harms associated with constitutional adjudication in the realm of religion. These analytical and practical effects of law's intervention in the politics of religious freedom are strongest, I suggest, when we think about law in a way that grounds its authority and utility in its better vantage point on the world as it is or as it should be. In a global constitutional environment in which legal instruments and human rights are held up as responses to all manner of social and political ill, this way of imagining law is natural enough. This is law in a decisional mode, serving as an institution to which we look for a statement of political and normative truth in the midst of deep difference on matters of theory, principle, and practice. Fidelity to certain rights and political principles may sometimes

\footnotetext{
70 “Incompletely Theorized Agreements," 1748.

${ }^{71}$ Canadian examples might include the celebrated "Persons Case," in which the Judicial Committee of the Privy Council held that the word "persons" in the Canadian Constitution included women (Edwards v. Canada, [1930] A.C. 124 (18 October 1929), P.C. (on appeal from Canada)) or the Supreme Court of Canada's decision in United States v. Burns and Rafay, [2001] 1 SCR 283, effectively declaring the death penalty unconstitutional.
} 
impel this more ambitious use of law. When this is so in the realm of religious freedom, the critical literature serves to caution and remind us about the points of inconsistency, the cultural blind spots, and the partiality that afflict law when it acts in this mode. These "vices" of law in matters of religious freedom impact on the theoretical satisfaction that we might hope to find in adjudication, as well as on the individual and collective experience of adjudication on matters of religion.

But law and legal actors can move in many ways, and this article has sought to identify and redeem salutary aspects of legal process that, when emphasized in adjudication, may offer possibilities for intervening in and providing relief from the politics of religious difference. Emphasizing the comfort with provisionality and tendency to incompleteness that are also features of adjudication, one discovers another mode for law, a role that can offer something of social value in contexts of deep religious and normative diversity. Looking at the very different settings of Canada and Israel, one finds moments in which, when comprehensive claims are in vigorous and sometimes volatile circulation in public life, an adjudicative mode that leverages law's artificiality can yield claims that are true enough to be agreed upon and solutions that are good enough to allow us to carry on, bracketing both grand theories and excessive prescriptiveness in favour of something "workable."72 In contrast to an oracular law directed at revealing the true or the just, in these moments law draws its worth from its tolerance for ambiguity, its sub-theoretical nature, and its pragmatic proceduralism. One might say that, in such instances, law's modesty becomes its chief virtue, ${ }^{73}$ as it seeks to sustain political community in the presence of normative diversity, rather than speaking truth to difference.

If such moments indeed suggest a virtue for law between politics and religion, they are also points at which a court will be subject to the criticism

\footnotetext{
${ }^{72}$ I am put in mind of the concept of "workable truths" explored in Joyce Oldham Appleby, Lynn Avery Hunt, and Margaret C. Jacob, Telling the Truth About History (New York: Norton, 1994) and described by Dipesh Chakrabarty as "shared, rational understanding of historical facts and evidence." Chakrabarty explains as follows: "For a nation to function effectively even while eschewing any claims to a superior, overarching grand narrative, these truths must be maintained in order for institutions and groups to be able to adjudicate between conflicting stories and interpretations." Provincializing Europe: Postcolonial Thought and Historical Difference (Princeton, NJ: Princeton University Press, 2000), 99.

${ }^{73}$ For a claim about the appeal of institutional "humility" for law in the realm of identity politics, see Avigail I. Eisenberg, Reasons of Identity: A Normative Guide to the Political and Legal Assessment of Identity Claims (Oxford: Oxford University Press, 2009). I have written elsewhere about humility as an "adjudicative virtue" in the realm of law and religion, rather than as a principle for institutional design, as Eisenberg does in her excellent volume.
} 
that it evaded the tough choice, should have decided more, or ought to have flexed its normative muscles more enthusiastically. I have identified different aspects of what legal process might have to offer to the politics of religious difference, different modes and styles in which it might act. Deciding which mode-the oracular or the strategically agnostic-is appropriate to a given issue or case will always be a substantial and important challenge. In some instances, the value of law will be measured by its ability to vindicate a principle, a way of life, or a theory of justice; in others, conceptual satisfaction, with its winners and losers, may be a luxury that a deeply divided society cannot afford. Pluralizing our sense of what law and adjudication might offer to conflicts involving deep normative diversity, one can find significant virtue in law's capacity to serve as a tool of adhesion, rather than ultimate decision, and a temporary relief from the hyper-realism of the politics of religious difference. 